\title{
Sex Working and the Bible, by Avaren Ipsen
}

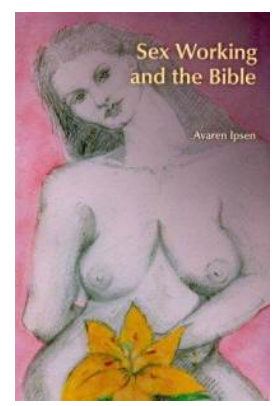

BibleWorld | Sheffield: Sheffield Phoenix Press, 20 Io |x +237 pages | ISBN: 978-I-84553-332-8 (hardback) £60.00 | ISBN: 978-I-84553-333-5 (softback) £I9.99

Avaren Ipsen's revision of her $\mathrm{PhD}$ dissertation, Sex Working and the Bible, is an eclectic mix of biblical stories pitched into modern day interpretations by sex worker rights activists from SWOP-USA (Sex Worker Outreach Project, USA). Ipsen herself is a supporter of the decriminalisation of sex work, and has served as the vice-chair of the Berkeley Commission on the Status of Women.

It is an engaging read, examining four biblical stories featuring prostitutes: Rahab's deal with the two Israelite spies, Solomon and the two prostitutes, the woman who anointed Jesus and Mary Magdalene, and the Whore of Babylon. This book is, perhaps, unique, as it is usually non-sex workers who describe, and assume, the reality for sex workers, typically in pitying tones. As sex workers' voices are often muted at the best of times, it is enlightening to have these strong articulate voices come through as they analyse the biblical stories in Ipsen's book.

One example is the sex workers' discussion of Solomon and the two prostitutes. In presenting this discussion, Ipsen foregrounds the manner in which 
contemporary sex workers who are seeking to deal with the criminal justice system come before it as "criminals" and "unfit mothers" who "are commonly seen as 'getting what they deserve' when they are assaulted, raped, murdered, coerced or blackmailed" (97). The SWOP activists discussing this biblical story did not interpret it as a story of Solomon demonstrating his wisdom so much as "a negative depiction of justice for prostitutes or mothers in general, because Solomon uses the threat of violence to dispense justice." Scarlot comments, "Yeah, it was a bluff. It's still abusive, and it's still sick... in a story that really should be focused on this violence.... I still say that the overriding situation in this is that it is ridiculous this king is going to cut the baby in half!" (98). Scarlot's comments reflect other sex workers' opinions that as mothers they are vulnerable to encountering bad experiences with the judicial system. As Ipsen also observes, the sex workers view the story as unrealistic insofar as it presents violence occurring between two prostitutes, but as realistic in respect of its depiction of "violent abusive treatment by the legal establishment."

In discussing the Whore of Babylon in Revelation, some of the sex workers perceive that the story reflects the idea of the feared power of the 'whore' and some also believe that there is a repressed goddess within the image. However, most of the sex workers point to the text as being the divine sanctioning of violence against them. Ipsen, discussing the close connection of the image of the whore with violence against women, summarises: "The whore metaphor is just all around bad news to prostitutes" (I 70).

Many of the sex workers identify with Mary Magdalene, and view her as a reason for religious people to support them, holding the relationship Jesus had with her as an example of justice towards a sex worker. The story of the anointing woman-often assumed to be Mary Magdalene, but named as Mary of Bethany the sister of Lazarus only in the version in John—sparks the strongest reaction. While some scholars have held her up as a symbol of forgiveness, these sex workers are appalled that Jesus would consider prostitution a sin, patronizingly meting "out his forgiveness to the poor person that is all like, at his feet." Kimberlee thus likens Jesus to that of "a dominating prick," and Scarlot summarises that Jesus's behaviour "is really nasty" (I 47).

Unlike their counterparts in New Zealand, where sex work has been decriminalised and sex workers experience the protection of the law, sex workers in America in large part work in a criminalised environment and have no obvious pathway to seek justice. They are very often victims of law enforcement, and see the police and the state as their persecutor, rather than 
as their ally in protecting them. Even in the decriminalised New Zealand context, stigma still attaches to sex workers, and so it is possible they, too, would read these passages in a similar way. Custody battles, violence, and neighbourhood antagonisms, betrayal and rejection can still be played out to the detriment of the sex worker. As Ipsen points out, one step in addressing these legal and social injustices is by examining their biblical and other religious foundations (2).

Ipsen's thinking is often at odds with what many people would have been taught in Church and Sunday School, bringing a fresh perspective to old stories and traditional thinking. As she summarises, the reports of her discussions with SWOP readers "have brought rich interpretive insights to ... passages of biblical prostitution" (207), and these thoughtful perspectives should challenge our thinking of those biblical passages and of prostitution itself.

Catherine Healy The New Zealand Prostitutes' Collective 